\title{
A Reexamination of Earnings Persistence on the Incremental Value Relevance of Earnings Levels and Earnings Changes
}

\author{
Simon Yang \\ Accounting and Law Department, Adelphi University, USA \\ E-mail:yang@adelphi.edu
}

Received: May 18, 2018

Accepted: June 1, 2018

Published: June 10, 2018

doi:10.5296/ijafr.v8i2.13160

URL: https://doi.org/10.5296/ijafr.v8i2.13160

\begin{abstract}
This study reexamines the role of earnings persistence as to understand the incremental value relevance of earnings levels and earnings changes in explaining stock returns in the stock market of U.S. The results show that earnings levels and earnings changes together provide the higher value relevant information than each earnings variable alone in explaining stock returns. An increase in earnings persistence, approximated by different time-serial and firm-specific measures, puts more (less) value relevant weight on earning changes (levels). However, the complementary value relevance between earnings levels and earnings changes is somehow weak, implying that a possibly deteriorating valuation role for earnings levels and earnings changes may occur in the recent years for the U.S. stock market.
\end{abstract}

Keywords: Earnings persistence, Value relevance, Return-earnings relationships

\section{Introduction}

A substantial body of research dated back to Ball and Brown (1968) examines the association of accounting earnings and stock returns in the U.S. equity market. Over the years, numerous studies (e.g., Balchandran and Mohanram (2011); Dichev and Tang (2008); Francis and Schipper (1999); Brown et al. (1999)) document a significant decline in the value relevance of accounting earnings in explaining equity values of the U.S. stock market. (Note 1) The value relevance of accounting information for equity market becomes even more complicated when accounting earnings are used in conjunction with the book value of owners' equities. For example, while studies agree unanimously on a deteriorating relationship between earnings and stock prices over the years, the results for the combined relevance of both earnings and book value are mixed. Some studies find an increase in the combined relevance of earnings and book value in explaining market equity values (e.g., Collin, Maydew and 


\section{Mll Macrothink}

International Journal of Accounting and Financial Reporting

ISSN 2162-3082

2018, Vol. 8, No. 2

Weiss (1997) and Francis and Schipper (1999)) but others show otherwise (Chang (1999) and Brown, Lo and Lys (1999)).

The relative value relevance of book value and earnings on a level basis -- or earnings levels and earnings changes on a change basis -- has drawn significant attention in decades because both accounting measures provide summarized, correlated, yet different information from balance sheet and income statement, respectively. (e.g., Barth, Beaver and Landsman (1998)). Some studies suggest earnings level as a proxy for expected future earnings (e.g., Collins et al. (1999)); others posit earnings changes as current unexpected earnings. From a firm valuation perspective, the market value of a firm can be viewed as a weighted average of book value and earnings, where both variables relate to a firm's growth, risks, investment opportunities, or conservative accounting to different extent ((Zhang (2000); Penman and Zhang (2002); Ohlson and Shroff (1992)). In a traditional firm valuation model (e.g., Ohlson (1995)) where high earnings persistence is assumed, the value relevant role of earning levels and earnings changes is predicted to be complementary. However, most prior studies on value relevance focus mostly on one earnings variable alone or earnings changes over earnings levels. There are relatively few studies specifically examining the complementary role among earnings changes and earnings levels. As such, some important information of both earnings variables might be omitted or undermined. This paper attempts to address this issue and proposes that it is essential to re-examine the complementary value relevance of both earnings levels and earnings changes in order to have a better understanding of earnings-return relationship for the U.S. stock market over the recent years.

One key attribute affects both earnings variables is earnings persistence. Earnings persistence -- the extent to which current-period information shocks to income recur in the future period -- is found to play an important role in the earnings-return relationship because the determinants of earnings persistence relate closely to key properties of firm value. Empirical studies find that earnings persistence is associated with earnings variability, performance sustainability, accounting conservativism, earnings management, trend of profitability, accrual quality, managerial incentive, and the predictability of future cash flows (e.g., Dechow, Ge and Schrand (2010); Subramanyam and Wild (2009), Dechow and Dichev (2002), Lev and Thiagarajan (1993), and Lipe (1990)). While the academic literature has placed a strong emphasis on exploring the relationship between earnings persistence and firm value, discrepancies still largely exist among recent empirical findings, standard settings and accounting practices (Dichev et al. (2013)).

For instance, a substantial decline in earnings persistence has been documented in empirical findings where earnings volatility is nearly double, the reversibility (i.e., negative autocorrelation) of earnings changes increases significantly, and a trend of weakening contemporaneous correlations between revenues and expenses occurs over time (Dichev and Tang (2008)). However, other studies on the determinants of earnings persistence somehow convey mixed messages. The ability of current earnings in predicting future operating cash flows is found to be strengthened, not weakened, over time (Kim and Kross (2005)). No clear relation is found between earnings smoothness and average stock returns over last 30 years, implying that firms with persistent earnings are not fully compensated in the equity market 


\section{Macrothink}

International Journal of Accounting and Financial Reporting

ISSN 2162-3082

(McInnis (2010)). Nor is the relationship found between increases in conservatism and declines in value relevance of accounting measures (Balachandran and Mohanram. (2011)). Because of the existence of empirical discrepancies, calling for further examinations on earnings persistence and earnings quality is still on high demand (Dechow et al. (2010)).

In addition, accounting practice in U.S. indeed has changed tremendously over time, especially after the economic recession, the harmonization of global accounting standards, and the passage of more rigorous regulations on accounting frauds in response to the collapse of Enron and WorldCom. These mixed empirical results and rapid changes in accounting practices suggest a reexamination of earnings persistence and firm value be necessary. These inconsistences also indicate the importance of revisiting and updating our understandings on whether there are deteriorating effects of earnings persistence on the valuation roles of earnings variables over the recent years.

As such, this paper reexamines the effects of earnings persistence on the value relevance of accounting levels and changes in the recent years. This paper is different from prior studies examining the value relevance of earnings in two ways: empirical testing and the estimation of earnings persistence. First, the paper examines the incremental value relevance of earnings, a term defined as the difference of the joint value relevance of both earnings levels and earnings changes over that of each alternative accounting variable. Operatively, the incremental value relevance of earnings levels (changes) is approximated by comparing the combined value relevance of both accounting variables with an alternative earnings-changes (level)-only model. In this paper, a joint model was first used as a comparable benchmark for both earnings changes and earnings levels, and then was evaluated against each alternative earnings variable to estimate the incremental value relevance of corresponding variable. This approach is expected to reduce possible estimation errors and in-sample variations (e.g., Liu and Thomas (2000)) in examining the valuation roles of two earnings variables and helps us to see the complementary and incremental value relevance of both earnings variable for the different levels of earnings persistence.

Secondly, this paper uses different time-serial measures of earnings persistence to examine the complementary value relevance of both earnings variables. Prior studies (e.g., Ou and Penman (1989)) show that the use of different proxies for earnings persistence may cause different effects on earnings variables. In comparison with other earnings persistence measures, the use of time-series properties to approximate earnings persistence is consistent with the proposition made by firm valuation (Ohlson (1995)) and allows us to examine the complementary role of earnings variables. This paper finds that the value relevance of earnings levels and earnings changes in explaining stock returns still, though somehow marginally, reflects information in a complementary and opposite manner as earnings persistence varies, implying a possible decline in the joint value relevance in the recent years.

The remainder of the paper is organized as follows. Section 2 discusses theoretical links between our measure of earnings persistence and prior measures. Section 3 discusses the incremental value relevance. Section 4 describes our sample data. Section 5 presents empirical results, and section 6 concludes the paper. 


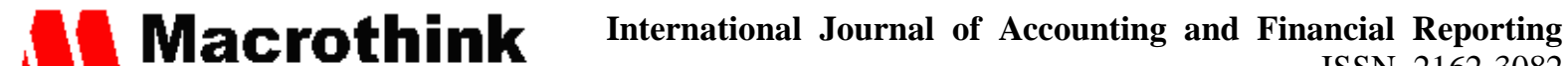 ISSN 2162-3082 2018, Vol. 8, No. 2}

\section{Literature Review, Analytical Model and Research Design}

\subsection{Literature Review on Earnings Persistence}

Early studies examining the time-series properties of earnings maintain that most accounting incomes follow a submartingale (or random walk) process (Beaver (1970); Ball and Watts (1972)), a proposition implying that earnings levels are largely sustainable and earnings changes are expected to exhibit a mean-reverting process. Prior studies indeed find that firms with large earnings changes are found to be less persistent than those with small changes and are more likely to revert back to an averaged mean (Brook and Buckmaster (1976)).

Earnings persistence, a measure of the continuity and durability of the current earnings, was first defined as the present value of the revisions in expectations of current and future earnings (Lipe (1990) and (1986)). The persistence of earnings is of considerable interest to researchers because it provides a strong link between accounting information and firm performance. For instance, prior studies document a positive relation between earnings persistence and earnings response coefficients (e.g., Kormendi and Lipe (1987), Collins and Kothari (1989), Easton and Zmijewski (1989), and Kothari (2001)). In addition, studies find earnings persistence related to the usefulness of cash flows (Cheng et al. (1996)), the relative weight on earnings variables and book value (Ohlson (1995); Ali and Zarowin (1992a); Ohlson and Shroff (1992)), accrual quality and predictability (e.g., Dechow and Dichev (2002), Lev and Thiagarajan (1993), and Lipe (1990)). (Note 2)

In reviewing the accounting literature, Dechow et al. (2010) link the importance of earnings persistence to two streams of academic research: firm performance and equity investment decision, suggesting that earnings with higher persistence are expected to have better quality and are more relevant to equity valuation. However, some concerns rest upon the measurement of earnings persistence because it is difficult to disentangle a firm's fundamental performance from its accounting system, where managerial discretion, stewardship practice, incentive contract, earnings management, and economic and industry-wide conditions are all overwhelmingly intertwined (Dichev et al. (2013)).

Recent studies on earnings persistence tend to focus on decomposing accounting earnings into more subtle components to search for the source of persistent properties of earnings. This line of literature shows that while noncash (e.g., accruals) sources of income are less persistent than cash sources of income, investors seem to fixate on earnings information as a whole and fail to distinguish the different levels of persistence on earnings components in explaining stock return in the U.S. equity market (e.g., Sloan (1996)). Further decompositions on accounting earnings are also well documented where examples may include studies on negative special items (Cready, Lopez, and Sisneros (2010)), firm-specific and time-specific earnings components (Francis and Smith (2005)); discretionary and non-discretionary accruals (Xie (2001)), operating investment (Fairfield, Whisenant and Yohn (2003)), book-tax differences (Hanlon (2005)), and equity/debt-related cash flows (Dechow, Richardson and Sloan (2008)). Using earnings decomposition to proxy for earnings persistence continues to be one of the main research interests in accounting and finance studies. However, the effect of earnings components is often short-term and fast reversible so 


\section{MIN Macrothink}

International Journal of Accounting and Financial Reporting

ISSN 2162-3082

2018, Vol. 8, No. 2

that the time-serial properties of earnings persistence and their effects on earnings variables may be missed. Also, the decomposition of earnings into small components might lose the important information between earnings levels and earnings changes as a whole.

Though the investigation of the effects of earnings persistence on equity variations remains popular in academic pursuits (Wang (2014); Dechow et al. (2010)), little attention has been paid to examine the combined and complementary effects of earnings changes and earnings levels in relation with earnings persistence over years. Given rapid and structural changes of economic conditions, accounting practices, and incongruent empirical results, evidences seem to suggest a need for more careful and comprehensive re-examination on earnings persistence for the U.S. stock market in the recent years. In response to this call, this paper uses different time-serial measures for earnings persistence to re-examine the incremental value relevance of earnings levels and earnings changes and to revisit the complementary valuation roles of both earnings variables in the recent years.

\subsection{The Relative Value Relevance of Earnings Changes and Earnings Levels}

The joint value relevance of earnings and owner's equity in explaining stock prices can be examined by two approaches: (1) price approach - using contemporaneous earnings and book value to explain stock prices; or (2) return approach - using earnings levels and earnings changes as measures for equity value (Penman and Zhang (2002); Balachandran and Mohan ram (2011)). This paper adopts a return approach because prior studies argued that the joint value relevant roles of earnings and book value will be skewed if the lagging price is not controlled for (Brown, Lo, and Lys (1999)).

Following the residual earnings valuation model (Ohlson (1995)), this paper describes the relation between prices, accounting earnings, book value and other information as follows: (Note 3)

$$
\mathrm{P}_{\mathrm{t}}=k\left(\rho \mathrm{X}_{\mathrm{t}}-\mathrm{d}_{\mathrm{t}}\right)+(1-k) B_{\mathrm{t}}+\alpha v_{\mathrm{t}}
$$

where

$$
\begin{array}{ll}
\mathrm{P}_{\mathrm{t}} & =\text { price per share at time } t, \\
\mathrm{X}_{\mathrm{t}} & =\text { accounting earnings per share at time } t, \\
\mathrm{~d}_{\mathrm{t}} & =\text { dividends per share at time } t, \\
B_{\mathrm{t}} & =\text { book value of owners' equity per share at time } t, \\
v_{\mathrm{t}} & =\text { price relevant information not captured in either earnings or book value, } \\
k & =\text { relative weighting factor on earnings and book value, } 0 \leq k \leq 1, \text { and } \\
k & =(\mathrm{r} \omega) /(1+\mathrm{r}-\omega), \\
\rho & =(1+\mathrm{r})^{-1}, \text { with } \mathrm{r}=\mathrm{expected} \mathrm{rate} \mathrm{of} \mathrm{return,} \mathrm{and} \\
\alpha & =(1+\mathrm{r})(1+\mathrm{r}-\omega)^{-1}(1+\mathrm{r}-\phi)^{-1} \text { with } \omega=\text { autocorrelation in abnormal } \\
& \quad \text { earnings, } X_{t+1}^{a}, \text { where they are defined as } X_{t+1}^{a}=X_{t+1}-\mathrm{r} B_{t} \text { and } X_{t+1}^{a}=
\end{array}
$$


$\omega X_{t}^{a}+v_{t}+\varepsilon_{t+1}$, and $\phi=$ the first order autoregressive parameter of non-financial statement information, i.e., $v_{\mathrm{t}+1}=\phi v_{\mathrm{t}}+\varepsilon_{\mathrm{t}+1}$.

Assuming that a clean surplus relation and a constant dividend policy are held, we take the first difference and scale all the variables with lagged price to yield the following equation:

$$
\mathrm{R}_{\mathrm{t}}=k \rho\left(\Delta \mathrm{X}_{\mathrm{t}} / \mathrm{P}_{\mathrm{t}-1}\right)+(1-k)\left(\mathrm{X}_{\mathrm{t}} / \mathrm{P}_{\mathrm{t}-1}\right)+\alpha \Delta \mathrm{v}_{\mathrm{t}} / \mathrm{P}_{\mathrm{t}-1}
$$

where $R_{t}$ is a realized return including dividends from period $t-1$ to $t$, and $\Delta X_{t}$ and $X_{t}$ are earnings changes and earnings levels at time $t$, respectively. Many previous studies (e.g., Easton and Harris (1991), Ali and Zarowin (1992a), Easton, Eddey and Harris (1993), Francis and Schipper (1999), Cheng et al. (1996), and Lev and Zarowin (1999)) have used equation (2) to investigate the value relevant roles of earnings levels and earnings changes.

Note that Ohlson (1995) defines the relative weight coefficient, $k$, to be equal to $(\mathrm{r} \omega) /(1+\mathrm{r}$ $-\omega)$. As such, equation (2) implies that the weighting factor is positively associated with the persistence of abnormal earnings. (Note 4) The more persistent the abnormal earnings, the more (less) weight is assigned on earnings changes (levels) as an explanatory variable for returns (Gode and Ohlson (2000)). In other words, the persistence parameter, $\omega$, determines the relative importance of earnings changes and earnings levels in the earnings-return relation.

\subsection{Measure of Earnings Persistence}

\subsubsection{Time-Series Measure: ARIMA $(0,1,1)$ Specification}

The use of time-series ARIMA $(0,1,1)$ model to measure earnings persistence has been popular in the accounting studies (e.g., Ball and Watts (1972), Beaver, Lamber and Morse (1980), Collins and Kothari (1989), and Baber et al. (1999)). A time-series measure for earnings persistence based on an ARIMA $(0,1,1)$ process of earnings (i.e., $X_{t}=X_{t-1}+\varepsilon_{t}-\theta \varepsilon_{t-1}$ ) is developed as follows. To be compatible with prior studies (e.g., Baber et al. (1999)), this paper truncates earnings after the first lag so that unexpected earnings can be expressed as follows:

$$
\begin{aligned}
\varepsilon_{\mathrm{t}} & =\mathrm{X}_{\mathrm{t}}-\mathrm{X}_{\mathrm{t}-1}+\theta \varepsilon_{\mathrm{t}-1} \\
& =\mathrm{X}_{\mathrm{t}}-(1-\theta) \mathrm{X}_{\mathrm{t}-1}-\theta(1-\theta) \mathrm{X}_{\mathrm{t}-2}-\theta^{2}(1-\theta) \mathrm{X}_{\mathrm{t}-3} \cdots \\
& \approx \mathrm{X}_{\mathrm{t}}-(1-\theta) \mathrm{X}_{\mathrm{t}-1} \\
& =\theta \mathrm{X}_{\mathrm{t}}+(1-\theta) \Delta \mathrm{X}_{\mathrm{t}}
\end{aligned}
$$

where $X_{t}$ is earnings at time $t, \varepsilon_{t}$ is unexpected earnings, and $\theta$ is a moving average parameter for the ARIMA $(0,1,1)$ process of earnings. Equation (4) implies that a measure of earning persistence, $(1-\theta)$, is positively (negatively) related to the ability of earnings changes (levels) as a proxy for unexpected earnings. 


\section{Macrothink}

International Journal of Accounting and Financial Reporting

ISSN 2162-3082

2018, Vol. 8, No. 2

\section{Incremental Explanatory Power and Incremental Information Content of Earnings Levels and Earnings Changes}

In this paper, both explanatory power (i.e., changes in adjusted $\mathrm{R}^{2} \mathrm{~s}$ ) and information content (i.e., changes in slope coefficient estimates) in the earnings-return relationship are used to measure the relative value relevance of earnings changes and earnings levels. Using both incremental explanatory power and incremental information content to examine the value relevance of earnings levels and earnings changes helps to clarify some discrepancies found in prior studies examining the valuation roles of earnings and book values. For example, some studies find a decline in value relevance, but others find an increase in the information content for accounting earnings (e.g., Buchheit and Kohlbeck (2002)). Since this paper examines conditions of earnings persistence affecting the relative valuation weights of earnings levels and earnings changes, using both parameters is able to provide a more comprehensive view on their complementary roles. The incremental value relevance comparison was theoretically derived by Theil (1971) and has been used to examine changes in the value-relevance of earnings and book value (Collins, Maydew and Weiss (1997) and Barth, Beaver, and Landsman (1998)).

Let

$$
\begin{aligned}
& \mathrm{R}_{t}=\beta_{0}+\beta_{1} \Delta \mathrm{X}_{t}+\varepsilon_{t} \\
& \mathrm{R}_{t}=\gamma_{0}+\gamma_{1} \mathrm{X}_{t}+\varepsilon_{t} \\
& \mathrm{R}_{t}=\alpha_{0}+\alpha_{1} \mathrm{X}_{t}+\alpha_{2} \Delta \mathrm{X}_{t}+\varepsilon_{t}
\end{aligned}
$$

The adjusted $\mathrm{R}^{2}$ s from empirical models of (M1), (M2), and (M3) are denoted as $\mathrm{R}^{2}{ }_{\triangle \mathrm{EPS}}$, $\mathrm{R}_{\text {EPS }}^{2}$, and $\mathrm{R}_{\text {COMB }}^{2}$, respectively. In this paper, the incremental explanatory power of earnings levels, Incre_ $R_{\text {EPS }}^{2}$, is defined as the difference in adjusted $R^{2}$ s between the combined model (i.e., M3) and the earnings changes only model (i.e., M1). That is, Incre $-R_{E P S}^{2}=R_{C O M B}^{2}$ $\mathrm{R}^{2}{ }_{\triangle \mathrm{EPS}}$. Similarly, Incre_ $\mathrm{R}^{2}{ }_{\triangle \mathrm{EPS}}\left(=\mathrm{R}_{\text {COMB }}^{2}-\mathrm{R}_{\text {EPS }}^{2}\right)$ reflects the incremental value relevance of earnings changes.

The incremental information content of earnings levels, Incre_Coeff $\mathrm{EPS}_{\text {, }}$, is defined as the sum of slope coefficients on earnings levels and earnings changes from (M3) minus the coefficient on earnings changes from (M1) and is divided by the sum of slope coefficients on earnings levels and earnings changes from (M3). That is, Incre_Coeff EPS $_{2}=\left(\alpha_{1}+\alpha_{2}-\beta_{1}\right) /\left(\alpha_{1}+\alpha_{2}\right)$ (see Ali and Zarowin (1992a)). Similarly, Incre_Coeff $\Delta \mathrm{EPS}=\left(\alpha_{1}+\alpha_{2}-\gamma_{1}\right) /\left(\alpha_{1}+\alpha_{2}\right)$.

\subsection{The Complementary Value Relevance of Earnings Changes and Earnings Levels}

The incremental explanatory power (i.e., change of $\mathrm{R}^{2} \mathrm{~s}$ ) and the incremental information content (i.e., percentage increase in slope estimates) for each earnings variable obtained above are then used to examine whether the value-relevance of earnings changes and levels is related to the different magnitudes of earnings persistence. We regress the incremental explanatory power and incremental information content of earnings changes (levels) on an index variable that indicates an increase in earnings persistence. 


$$
\begin{gathered}
\text { Incremental } \mathrm{R}_{\text {EPS }}^{2} \text { or } \mathrm{R}^{2}{ }_{\triangle \mathrm{EPS}}=\alpha_{0}+\alpha_{1} \tau+\mathrm{e}, \\
\text { Incremental Coeff_EPS or Coeff__EPS }=\alpha_{0}+\alpha_{1} \tau+\mathrm{e},
\end{gathered}
$$

where $\tau=1,2, \ldots .5$ denotes an index variable indicating an increase in earnings persistence with 1 donated as lowest and 5 highest. A significant and positive slope coefficient on $\tau$ is interpreted as an increase in the incremental explanatory power with earnings persistence.

\section{Data and Sample Selection}

Our sample is drawn from the U.S. actively traded companies for the period 1990 to 2011. The sample needs to meet the following criteria: (1) earnings per share before extraordinary and discontinued operations (EPSPX, item 58) are available on the 2011 version of COMPUSTAT; (2) monthly security returns (including dividends) are available on 2011 Center for Research in Security Prices (CRSP) database. All earnings, stock prices, and return data are adjusted for stock splits and dividends. In addition, (3) each firm is required to have at least 15 years of annual earnings and a non-stationary earning process. (Note 5)

The selection procedure yields 14,591 firm-year observations for firms listed on the NYSE, AMEX and NASDAQ. For empirical analysis of the earnings-return relation, this paper uses the price at the beginning of the period as a deflator for all explanatory variables (Christie (1987)). The annual buy-and-hold returns are computed by aggregating over the 12-month period beginning on the third month after the beginning of each firm's respective fiscal year. We use cumulative abnormal returns estimated from the market model as our primary dependent variable and use raw returns for a robustness test.

\section{Empirical Results}

Table 1 provides summary descriptive statistics for 14,591 firm years for the period of 1990-2011. Panel A reports that the mean of earnings changes scaled by the price at the beginning of the year is 0.005 (standard deviation $=0.068$ ). The mean and standard deviation for the 12-month cumulative raw returns, $\mathrm{R}_{\mathrm{t}}$, are 1.160 (or $16.0 \%$ ) and 0.381 , respectively.

Table 1. Descriptive statistics

Panel A: Descriptive statistics

\begin{tabular}{lccccc}
\hline & Mean & $\begin{array}{c}\text { Std. } \\
\text { Deviation }\end{array}$ & Median & $\begin{array}{c}\text { Upper } \\
\text { Quartile }\end{array}$ & $\begin{array}{c}\text { Lower } \\
\text { Quartile }\end{array}$ \\
\hline EPS & 0.067 & 0.080 & 0.073 & 0.107 & 0.039 \\
EEPS & 0.005 & 0.068 & 0.007 & 0.025 & -0.013 \\
Raw Returns, $\mathrm{R}_{\text {it }}$ & 1.160 & 0.381 & 1.118 & 1.351 & 0.912 \\
Cumulative Abnormal Returns, CAR $_{\text {it }}$, & 0.002 & 0.316 & 0.009 & 0.193 & -0.182 \\
Earnings Persistence, $(1-\theta)$ & 0.848 & 0.389 & 0.803 & 1.120 & 0.536 \\
\hline
\end{tabular}


Panel B: Earnings Persistence Measure based on (1- $\theta)$

\begin{tabular}{|c|c|c|c|c|c|}
\hline Earnings Persistence & $\begin{array}{c}1 \\
\text { (Lowest) }\end{array}$ & 2 & 3 & 4 & $\begin{array}{c}5 \\
\text { (Highest) }\end{array}$ \\
\hline $\mathrm{N}$ & 3063 & 3073 & 3076 & 3060 & 3071 \\
\hline \multicolumn{6}{|l|}{ Mean } \\
\hline$(1-\theta)$ & 0.352 & 0.594 & 0.808 & 1.048 & 1.440 \\
\hline \multicolumn{6}{|l|}{ Median } \\
\hline$(1-\theta)$ & 0.369 & 0.590 & 0.803 & 1.036 & 1.405 \\
\hline \multicolumn{6}{|l|}{ Standard Deviations } \\
\hline$(1-\theta)$ & 0.098 & 0.064 & 0.059 & 0.082 & 0.178 \\
\hline
\end{tabular}

Note: The total number of observation is 14,591 firm-years. EPS (Conpustat \#58 with a symbol EPSPX) denotes earnings before extraordinary items and discontinued operations on a per share basis for the period of 1990-2011. $\triangle$ EPS denotes changes in earnings per share, and $\mathrm{CAR}_{\mathrm{it}}$ is the 12-month cumulative abnormal returns estimated from the market model starting from the third month after the announcement of financial statements. Each firm is required to meet two criteria to estimate time-series parameters. It must have at least 15-years of annual earnings and have a non-stationary earnings process, which is tested by using the Augmented Dickey-Fuller (ADF) regression: $\Delta \mathrm{EPS}_{\mathrm{t}}=\alpha_{0}+\alpha \mathrm{EPS}_{\mathrm{t}-1}+\gamma_{1} \Delta \mathrm{EPS}_{\mathrm{t}-1}+\gamma_{2} \Delta \mathrm{EPS}_{\mathrm{t}-2}+v_{\mathrm{t} \text {. The EPS series represents }}$ a non-stationary process when $\alpha$ is insignificantly different from zero (Fuller (1976), Table 8.5.1)). Earnings persistence, $(1-\theta)$, is derived from an $\operatorname{ARIMA}(1,1)$ process of earnings, where $\theta$ is the firm-specific moving average parameter. In addition, we delete extreme observations when EPS or other variables lie above the $99^{\text {th }}$ or below $1^{\text {st }}$ percentile of their respective distributions.

Table 1 shows the mean of time-series parameters of ARIMA $(0,1,1)$ of earnings persistence, $(1-\theta)$, is 0.848 (with standard deviation $=0.389$ ), which is similar to 0.858 and the standard deviation 0.298 reported in Baber, Kang and Kumar (1999). Ali and Zarowin (1992b) report the median of $(1-\theta)=0.85$. The time period of our sample overlaps with some of early studies. Using a 10 percent discount rate for an ARIMA $(0,1,1)$ earnings process, Baginski, Lorek, Willinger and Branson (1999) report earnings persistence equal to 6.93 so that their derived earnings persistence is close to 0.630. Kormendi and Lipe (1987), who also assume a constant discount rate of 0.10 for all firms, find that $75 \%$ of firms' earnings persistence falls between 4 and 10. This implies that the majority of earnings persistence estimates, $(1-\theta)$, in their sample should be in the range of 0.4 and 1.0. As such, our earnings persistence estimate seems compatible with that of prior studies. Our estimate also seems to imply no significant changes of time-series measure for earnings persistence, $(1-\theta)$, over time.

Panel B of Table 1 reports descriptive statistics for earnings persistence: (1- $\theta)$ at different levels. The time-series estimates of earnings persistence, $(1-\theta)$, is ranked into five groups with an approximately equal number of observations from the lowest to the highest 


\section{Mll Macrothink}

International Journal of Accounting and Financial Reporting

ISSN 2162-3082

persistence group. The sample of this paper shows that the average earnings persistence for the lowest group is 0.352 , and that for the highest group is 1.440 .

Table 2 presents the results of earnings-return regressions employing three alternative earnings models: earnings changes only, earnings levels only, and combined models. As discuss above, the incremental explanatory power is defined as the adjusted $\mathrm{R}^{2}$ from the regression of the combined model less that of the earnings levels (or changes) only model. Vuong's (1989) Z-statistic is used to test the statistical difference in the incremental value relevance between earnings levels and earnings changes. Table 2 also provides statistics on the incremental information content by comparing changes in slope coefficients on earnings levels and earnings changes.

Table 2. Incremental value relevance and information content of earnings levels and earnings Changes

$$
\begin{aligned}
& \text { Earnings Changes Only Model (1): } C A R_{j t}=\beta_{210}+\beta_{211} \Delta E P S_{j t}+\delta_{t} \text {, } \\
& \text { Earnings Levels Only Model (2): CAR } \beta_{j t}=\beta_{220}+\beta_{221} E P S_{j t}+\delta_{t}, \\
& \text { Combined Model (3): CAR } R_{j t}=\beta_{230}+\beta_{231} \Delta E P S_{j t}+\beta_{232} E P S_{j t}+\delta_{t} .
\end{aligned}
$$

\begin{tabular}{|c|c|c|c|}
\hline & $\begin{array}{c}\text { Model } 1 \\
\text { (Earnings Changes) } \\
\text { (1) }\end{array}$ & $\begin{array}{c}\text { Model } 2 \\
\text { (Earnings Levels) } \\
\text { (2) }\end{array}$ & $\begin{array}{c}\text { Model } 3 \\
\text { (Earnings Levels and } \\
\text { Changes) } \\
\text { (3) }\end{array}$ \\
\hline $\begin{array}{l}\text { Panel A: Respo } \\
\text { Combined Mode }\end{array}$ & nt Estimates and Ex & ry Power of Earnin & ges, Earnings Levels a \\
\hline Intercept & $\begin{array}{l}-0.005 \\
(-2.00)^{*}\end{array}$ & $\begin{array}{c}-0.091 \\
(-27.95)^{*}\end{array}$ & $\begin{array}{c}-0.072 \\
(-21.72)^{*}\end{array}$ \\
\hline$\Delta \mathrm{EPS}$ & $\begin{array}{c}1.431 \\
(38.34)^{*}\end{array}$ & & $\begin{array}{c}0.856 \\
(20.82)^{*}\end{array}$ \\
\hline EPS & & $\begin{array}{c}1.386 \\
(44.12)^{*}\end{array}$ & $\begin{array}{c}1.041 \\
(29.66)^{*}\end{array}$ \\
\hline Adj. $R^{2}(\%)$ & 9.2 & 11.8 & 14.3 \\
\hline
\end{tabular}

Panel B: Test of Incremental Adjusted $\mathrm{R}^{2}$ and Slope Coefficients among Different Models

\begin{tabular}{lclc}
\hline \multicolumn{1}{c}{$\begin{array}{c}\text { Incremental Explanatory Power } \\
\text { (Changes in } \mathrm{R}^{2} \text { ) }\end{array}$} & \multicolumn{1}{c}{$\begin{array}{c}\text { Incremental Information Content } \\
\text { (Changes in Slope Coefficients) }\end{array}$} \\
\hline Model 3 (Combined Model) Adj. $\mathrm{R}^{2}$ & 14.3 & Model 3 (Combined Model) Sum Coefficients & 1.897 \\
EPS Incremental, Incre_R ${ }_{\text {EPS }}^{2}$ & 5.2 & EPS Incremental, Incre_R ${ }_{\text {EPS }}$ & $24.6 \%$ \\
$\Delta$ EPS Incremental, Incre_R ${ }_{\Delta \mathrm{EPS}}$ & 2.5 & EPS Incremental, Incre_R ${ }_{\Delta \mathrm{EPS}}$ & $26.9 \%$ \\
Vuong Z-statistics & $2.97^{* *}$ & Vuong Z-statistics & 1.05 \\
\hline
\end{tabular}

Note: The total number of observations is 14,591 firm-years. EPS (Conpustat \#58 with a symbol EPSPX) denotes earnings before extraordinary items and discontinued operations on a per share basis for the period of 1990-2011. Each firm is required to have at least 15 years of annual earnings and have a non-stationary earnings process. $* *$ denotes $p$-value $<0.01$. 


\section{Macrothink}

International Journal of Accounting and Financial Reporting

ISSN 2162-3082 2018, Vol. 8, No. 2

Following Barth, Beaver, and Landsman (1998), the incremental explanatory power is defined as the adjusted $\mathrm{R}^{2}$ from a regression of the earnings levels and earnings changes combined model, less the adjusted $\mathrm{R}^{2}$ from a regression with earnings levels (or changes) only model. Following Ali and Zarowin (1992a), the incremental information content is defined as the sum of slope coefficients on earnings levels and earnings changes from a regression of the combined model, less the slope coefficient from a regression with earnings levels (or changes) only model scaled by the summed coefficients. Vuong (1989) Z-statistic is used to test the statistical difference in the incremental value relevance between earnings levels and earnings changes.

Table 2 reports significant slope coefficients on both earnings change $(1.431, t=38.34)$ and level $(1.386, t=44.12)$ variables in cross-sectional pooled regressions. In year-to-year regressions (not reported here), the coefficients on the earnings levels and changes are all positive and significant (at the 0.01 level) in all 20 years for all models. In the combined model, it also shows that earnings levels and earnings changes have the incremental information content beyond each other.

Panel B of Table 2 provides the comparison between incremental explanatory power and incremental information content of earnings changes and those of earnings levels. Vuong test ( $\mathrm{Z}$ statistics $=2.97$ ) shows that the incremental explanatory power of earnings levels is, on average, significantly higher than that of earnings changes. However, the incremental information content reported in Panel B shows that percentage changes of regression slope coefficients in earning levels and earnings changes are not significantly different ( $\mathrm{Z}$ statistics $=1.05$ with $24.6 \%$ and $26.9 \%$, respectively).

Although a positive correlation between earnings changes and levels may cause multi-collinearity and may weaken the statistical significance, the finding indicates that the adverse effect does not prevent this paper from observing a significant difference in incremental explanatory power of earnings changes and earnings levels. Such an argument is not uncommon to prior research. Studies such as Cheng et al. (1996), Barth et al. (1998), and Subramanyam and Wild (1996) all provide a similar interpretation of their results.

In sum, it is found that the adjusted $\mathrm{R}^{2}$, $\mathrm{s}$ are larger when both earnings levels and earnings changes are jointly included than when only one of earnings variables is considered alone. Table 2 also suggests that the inclusion of earnings levels beyond earnings changes generally provides stronger value-relevant information in explaining stock returns than the inclusion of earnings changes beyond earnings levels.

Table 3 reports the effect of earnings persistence on the incremental value relevance of earnings changes and levels when ARIMA $(0,1,1)$ parameters are used to estimate earnings persistence. 
Table 3. Effects of earnings persistence measured by time-series ARIMA $(0,1,1)$ process on the incremental value relevance and information content of earnings changes and earnings levels

$$
\begin{aligned}
& \text { Earnings Changes Only Model (1): CAR } R_{j t}=\beta_{510}+\beta_{511} \Delta E P S_{j t}+\delta_{t} \\
& \text { Earnings Levels Only Model (2): CAR } R_{j t}=\beta_{520}+\beta_{521} E P S_{j t}+\delta_{t} \\
& \text { Combined Model (3): } C A R_{j t}=\beta_{530}+\beta_{531} \Delta E P S_{j t}+\beta_{532} E P S_{j t}+\delta_{t}
\end{aligned}
$$

\begin{tabular}{|c|c|c|c|c|c|c|c|c|c|c|c|}
\hline \multirow[t]{2}{*}{ Persistence } & \multirow[t]{2}{*}{$\mathbf{N}$} & \multicolumn{5}{|c|}{ Model 1} & \multicolumn{4}{|c|}{ Model 2} & \multirow{2}{*}{$\begin{array}{c}\text { Model } 3 \\
\text { Adj. R2 } \\
(\%)\end{array}$} \\
\hline & & Inter. & $\Delta$ EPS & $\begin{array}{c}\text { Adj. R2 } \\
(\%)\end{array}$ & Inter. & EPS & $\begin{array}{c}\text { Adj. R2 } \\
(\%)\end{array}$ & Inter & $\Delta$ EPS & EPS & \\
\hline \multirow[t]{2}{*}{1 (Lowest) } & 2917 & -0.013 & 1.418 & 8.6 & -0.090 & 1.287 & 10.8 & -0.071 & 0.841 & 0.949 & 13.0 \\
\hline & & $(-2.27)$ & $(16.62)$ & & $(-12.79)$ & $(18.77)$ & & $(-9.75)$ & $(8.78)$ & (12.19) & \\
\hline \multirow[t]{2}{*}{2} & 2917 & -0.007 & 1.032 & 6.4 & -0.085 & 1.279 & 12.9 & -0.076 & 0.345 & 1.117 & 13.4 \\
\hline & & $(-1.23)$ & (14.13) & & $(-12.69)$ & $(20.82)$ & & $(-10.77)$ & (4.15) & (15.41) & \\
\hline \multirow[t]{2}{*}{3} & 2917 & -0.004 & 1.351 & 10.1 & -0.088 & 1.367 & 12.7 & -0.070 & 0.826 & 1.018 & 15.6 \\
\hline & & $(-0.64)$ & (18.17) & & $(-12.17)$ & (20.60) & & $(-9.62)$ & (10.13) & (13.79) & \\
\hline \multirow[t]{2}{*}{4} & 2917 & -0.004 & 1.613 & 10.7 & -0.095 & 1.458 & 11.9 & -0.075 & 1.104 & 1.070 & 16.0 \\
\hline & & $(-0.70)$ & $(18.72)$ & & $(-12.75)$ & (19.82) & & $(-10.09)$ & $(12.05)$ & (13.60) & \\
\hline \multirow[t]{2}{*}{5 (Highest) } & 2923 & -0.003 & 2.296 & 12.5 & -0.109 & 1.681 & 10.9 & -0.082 & 1.720 & 1.151 & 16.8 \\
\hline & & $(-0.54)$ & $(20.43)$ & & $(-12.79)$ & (18.89) & & $(-9.75)$ & (14.44) & (12.31) & \\
\hline
\end{tabular}

Panel A: Earnings Persistence Measured by ARIMA(1,1) Parameters and Accounting Earnings

Panel B: Tests of Earnings Persistence Measured by ARIMA(1,1) Parameters on Incremental Value Relevance and Information Content of Earnings Changes and Earnings Levels

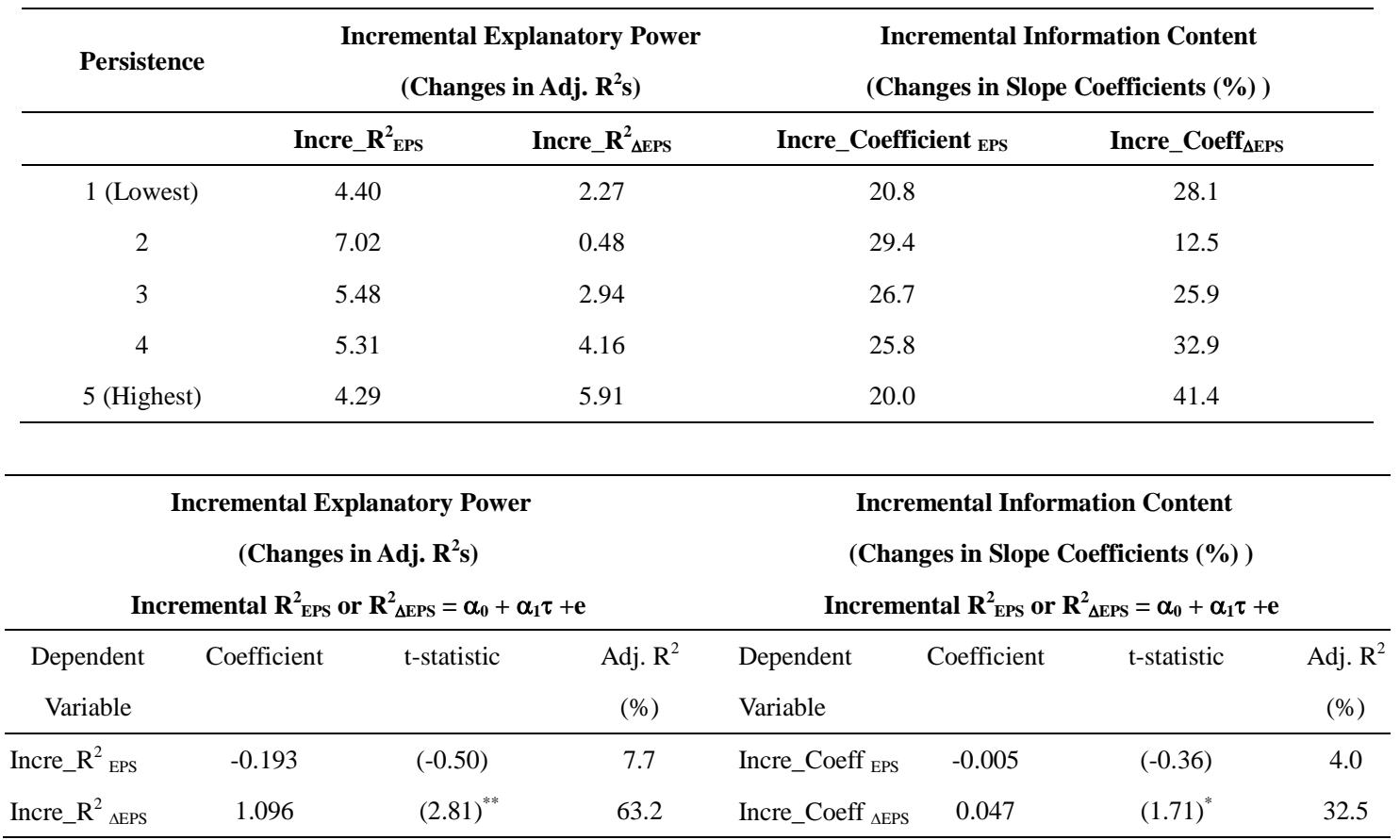

Note: The total number of observations is 14,591 firm-years. EPS (Conpustat \#58 with a symbol EPSPX) denotes earnings before extraordinary items and discontinued operations on a per share basis for the period of 
1990-2011. Each firm is required to have at least 15 years of annual earnings and have a non-stationary earnings process. Earnings persistence is derived from $(1-\theta)$ and is ranked equally into five portfolios, where $\theta$ is the firm-specific moving average parameter. As in the prior tables, the incremental value relevance and information content are defined as follows.

$$
\begin{aligned}
& \text { Incre_ } R_{\text {EPS }}^{2} \quad=\text { the incremental value relevance of earnings levels, denoting the difference in adjusted } R^{2} \mathrm{~s} \\
& \text { between combined model (i.e. model 3) and earnings changes only model (model 1). }
\end{aligned}
$$

$* *$ denotes $p$-value $<0.01$ (one-tail) and * denotes $p$-value $<0.05$ (one-tail)

Panel B of Table 3 shows that the earnings persistence has a positive effect on the information content and explanatory power of earnings changes. In the combined model, slope coefficient estimates on earnings changes tend to increase (except for the lowest group), and those on earnings levels tend to be invariant to an increase in earnings persistence. The result of Table 3 confirms that the additional value relevance of earning levels (changes) is of particular importance when earnings persistence is low (high) by illustrating that Incre_ $\mathrm{R}_{\text {EPS }}^{2}$ and Incre_Coefficent EPS are consistently larger than Incre_ $\mathrm{R}^{2}{ }_{\triangle \mathrm{EPS}}$ and Incre_Coefficent $\triangle \mathrm{EPS}$ in groups with low persistence.

More importantly, Panel B shows that the incremental value relevance of earnings levels and that of earnings changes are complementary, though modestly significantly, to each other. An increase in earnings persistence causes an increase in the incremental explanatory power of earnings changes $(1.096, t=2.81)$ and no decrease (but in right sign) in that of earnings levels $(-0.193, t=-0.50)$. The signs of the incremental coefficient of earnings changes and earnings levels (-0.005 and 0.047, respectively) are also consistent as predicted where they are marginally complementary to each other.

Equation (4) predicts that the relative valuation weights on earnings changes and levels are complementary to each other. An increase in earnings persistence is expected to improve earnings changes and to weaken earnings levels as an incremental explanatory variable for stock returns. Our result from ARIMA $(0,1,1)$ shows that the complementary valuation roles between earnings levels and earning changes seems only moderate in our sample, suggesting a possibly deteriorating joint value relevance in the recent years.

Table 4 and 5 use the same empirical test in Table 3 but the proxy for earnings persistence is estimated from the time-series ARIMA $(1,1,0)$ and ARIMA $(0,1,2)$, respectively. Note that the complementary value relevance is assessed by regressing the incremental value relevance 


\section{NI Macrothink}

International Journal of Accounting and Financial Reporting

ISSN 2162-3082 2018, Vol. 8, No. 2

of each earnings variable against different levels of earnings persistence. As the earnings persistence increases, the incremental value relevance of earnings changes (levels) is expected to increase (decrease). Panel $\mathrm{B}$ of both tables show that the coefficients of Incre_R ${ }^{2}$ EPS and Incre_ $\mathrm{R}^{2} \triangle$ EPS are consistent with our prediction: as earnings persistence increase, a negative (positive) coefficient on earnings levels (changes).

For the time-series process of ARIMA $(1,1,0)$ in Table 4 , the coefficients of Incre_R ${ }^{2}$ EPS and Incre_R ${ }^{2}{ }_{\triangle E P S}$ are $-0.000, t=-0.04$ and $0.008, t=2.93$, respectively. For ARIMA $(1,1,0)$ in Table 5, they are $-0.007, t=-3.68$ and $0.006, t=1.79$, respectively. The result thus supports that an increase in earnings persistence gives more (less) weight on the incremental explanatory power of earnings changes (levels). Similarly, the incremental information content measured by percent changes in slope coefficients also has a negative sign on EPS (i.e., Incre_Coeff $\mathrm{EPS}_{\mathrm{ES}}:-0.021, t=-0.57$ and $-0.147, t=-8.81$ ) and a positive sign on $\triangle \mathrm{EPS}$ (i.e., Incre_Coeff $\left._{\triangle \mathrm{EPS}}: 0.073, t=2.16 ; 0.074, t=3.69\right)$ for ARIMA $(1,1,0)$ in Table 4 and ARIMA $(0,1,2)$ in Table 5 , respectively. Overall, this paper shows that using different time-series earnings persistence measures yield a similar result, in which the incremental value relevance and information content of earnings changes and levels are complementary.

Table 4. Effects of earnings persistence measured by time-series ARIMA $(1,1,0)$ process on the incremental value relevance and information content of earnings changes and earnings levels

$$
\begin{aligned}
& \text { Earnings Changes Only Model (1): CAR } R_{j t}=\beta_{610}+\beta_{611} \Delta E P S_{j t}+\delta_{t} \\
& \text { Earnings Levels Only Model (2): CAR } R_{j t}=\beta_{620}+\beta_{621} E P S_{j t}+\delta_{t} \\
& \text { Combined Model (3): CAR } R_{j t}=\beta_{630}+\beta_{631} \Delta E P S_{j t}+\beta_{632} E P S_{j t}+\delta_{t}
\end{aligned}
$$

\begin{tabular}{|c|c|c|c|c|c|c|c|c|c|c|c|}
\hline \multirow[t]{2}{*}{ Persistence } & \multirow[t]{2}{*}{$\mathbf{N}$} & \multicolumn{4}{|c|}{ Model 1} & \multicolumn{4}{|c|}{ Model 2} & \multicolumn{2}{|c|}{ Model 3} \\
\hline & & Inter. & $\Delta \mathbf{E P S}$ & $\begin{array}{c}\text { Adj. R2 } \\
(\%)\end{array}$ & Inter. & EPS & $\begin{array}{c}\text { Adj. R2 } \\
(\%)\end{array}$ & Inter & $\triangle \mathrm{EPS}$ & EPS & $\begin{array}{c}\text { Adj. R2 } \\
(\%)\end{array}$ \\
\hline 1 (Lowest) & 2810 & $\begin{array}{l}-0.020 \\
(-3.34)\end{array}$ & $\begin{array}{c}0.676 \\
(11.43)\end{array}$ & 4.4 & $\begin{array}{l}-0.061 \\
(-9.37)\end{array}$ & $\begin{array}{l}0.910 \\
(15.53)\end{array}$ & 7.9 & $\begin{array}{l}-0.055 \\
(-8.31)\end{array}$ & $\begin{array}{l}0.282 \\
(4.16)\end{array}$ & $\begin{array}{c}0.761 \\
(11.12)\end{array}$ & 8.4 \\
\hline 2 & 2802 & $\begin{array}{l}-0.023 \\
(-3.72)\end{array}$ & $\begin{array}{c}0.676 \\
(13.96)\end{array}$ & 6.5 & $\begin{array}{l}-0.042 \\
(-6.65)\end{array}$ & $\begin{array}{c}0.635 \\
(13.30)\end{array}$ & 5.9 & $\begin{array}{l}-0.038 \\
(-6.02)\end{array}$ & $\begin{array}{l}0.488 \\
(9.20)\end{array}$ & $\begin{array}{l}0.428 \\
(8.21)\end{array}$ & 8.6 \\
\hline 3 & 2812 & $\begin{array}{l}-0.007 \\
(-1.13)\end{array}$ & $\begin{array}{c}0.645 \\
(13.65)\end{array}$ & 6.2 & $\begin{array}{l}-0.030 \\
(-4.74)\end{array}$ & $\begin{array}{c}0.627 \\
(13.42)\end{array}$ & 6.0 & $\begin{array}{l}-0.027 \\
(-4.28)\end{array}$ & $\begin{array}{l}0.479 \\
(9.60)\end{array}$ & $\begin{array}{l}0.457 \\
(9.28)\end{array}$ & 8.9 \\
\hline 4 & 2808 & $\begin{array}{l}-0.016 \\
(-2.53)\end{array}$ & $\begin{array}{c}0.608 \\
(13.37)\end{array}$ & 5.7 & $\begin{array}{l}-0.054 \\
(-8.28)\end{array}$ & $\begin{array}{c}0.835 \\
(16.38)\end{array}$ & 8.7 & $\begin{array}{l}-0.058 \\
(-8.98)\end{array}$ & $\begin{array}{l}0.279 \\
(8.87)\end{array}$ & $\begin{array}{c}0.810 \\
(16.09)\end{array}$ & 11.2 \\
\hline 5 (Highest) & 2810 & $\begin{array}{l}-0.002 \\
(-0.38)\end{array}$ & $\begin{array}{c}1.515 \\
(16.07)\end{array}$ & 8.4 & $\begin{array}{l}-0.045 \\
(-6.47)\end{array}$ & $\begin{array}{c}0.849 \\
(13.12)\end{array}$ & 5.7 & $\begin{array}{l}-0.036 \\
(-5.22)\end{array}$ & $\begin{array}{c}1.231 \\
(12.45)\end{array}$ & $\begin{array}{l}0.567 \\
(8.46)\end{array}$ & 10.6 \\
\hline
\end{tabular}

Panel A: Earnings Persistence measured by ARI MA $(1,1,0)$ 
Panel B: Test of Earnings Persistence Measured by ARI MA $(1,1,0)$ on Incremental Value Relevance and Information Content of Earnings Changes and Earnings Levels

\begin{tabular}{|c|c|c|c|c|c|c|c|}
\hline \multicolumn{4}{|c|}{$\begin{array}{l}\text { Incremental Value Relevance } \\
\qquad\left(\text { Changes in Adj. } \mathbf{R}^{\mathbf{2}}\right)\end{array}$} & \multicolumn{4}{|c|}{$\begin{array}{l}\text { Incremental Information Content } \\
\text { (Changes in Slope Coefficients (\%) ) }\end{array}$} \\
\hline \multicolumn{4}{|c|}{ Incremental $\mathbf{R}_{\mathrm{EPS}}^{2}$ or $\mathbf{R}_{\Delta \mathrm{EPS}}^{2}=\alpha_{0}+\alpha_{1} \tau+\mathrm{e}$} & \multicolumn{4}{|c|}{ Incremental $\mathbf{R}_{\mathrm{EPS}}^{2}$ or $\mathbf{R}_{\Delta \mathrm{EPS}}^{2}=\alpha_{0}+\alpha_{1} \tau+\mathrm{e}$} \\
\hline Dependent & Coefficient & t-statistic & Adj. $R^{2}$ & Dependent & Coefficient & t-statistic & Adj. $\mathrm{R}^{2}$ \\
\hline Variable & & & $(\%)$ & Variable & & & $(\%)$ \\
\hline Incre_R ${ }_{\text {EPS }}^{2}$ & -0.000 & $(-0.04)$ & 0.6 & Incre_Coeff EPS & -0.021 & $(-0.57)$ & 9.8 \\
\hline Incre_R ${ }^{2}{ }_{\Delta \mathrm{EPS}}$ & 0.008 & $(2.93)^{* *}$ & 65.5 & Incre_Coeff ${ }_{\triangle \mathrm{EPS}}$ & 0.073 & $(2.16)^{* *}$ & 47.7 \\
\hline
\end{tabular}

Note: The total number of observations is 14,042 firm-years for the period of 1990-2011. Each firm is required to have at least 15 years of annual earnings and have a non-stationary earnings process. Earnings persistence is estimated from $1 /(1-\varphi)$, where $\varphi$ is the firm-specific autoregressive parameter. All definitions are the same as prior tables.

Table 5. Effects of Earnings Persistence Measured by Time-series ARIMA $(0,1,2)$ Process on the Incremental Value Relevance and Information Content of Earnings Changes and Earnings Levels

$$
\begin{aligned}
& \text { Earnings Changes Only Model (1): } C A R_{j t}=\beta_{710}+\beta_{711} \Delta E P S_{j t}+\delta_{t} \\
& \text { Earnings Levels Only Model (2): } C A R_{j t}=\beta_{720}+\beta_{721} E P S_{j t}+\delta_{t} \\
& \text { Combined Model (3): CAR } R_{j t}=\beta_{730}+\beta_{731} \Delta E P S_{j t}+\beta_{732} E P S_{j t}+\delta_{t}
\end{aligned}
$$

\begin{tabular}{|c|c|c|c|c|c|c|c|c|c|c|c|}
\hline \multirow[t]{2}{*}{ Persistence } & \multirow[t]{2}{*}{$\mathbf{N}$} & \multicolumn{5}{|c|}{ Model 1} & \multicolumn{4}{|c|}{ Model 2} & \multirow{2}{*}{$\begin{array}{c}\text { Model } 3 \\
\text { Adj. R2 } \\
(\%)\end{array}$} \\
\hline & & Inter. & $\Delta$ EPS & $\begin{array}{c}\text { Adj. R2 } \\
(\%)\end{array}$ & Inter. & EPS & $\begin{array}{c}\text { Adj. R2 } \\
(\%)\end{array}$ & Inter & $\Delta \mathrm{EPS}$ & EPS & \\
\hline 1 (Lowest) & 3044 & $\begin{array}{l}-0.027 \\
(-4.38)\end{array}$ & $\begin{array}{c}0.332 \\
(10.98)\end{array}$ & 3.8 & $\begin{array}{l}-0.050 \\
(-8.02)\end{array}$ & $\begin{array}{c}0.714 \\
(15.65)\end{array}$ & 7.4 & $\begin{array}{l}-0.052 \\
(-8.32)\end{array}$ & $\begin{array}{l}0.252 \\
(8.41)\end{array}$ & $\begin{array}{c}0.639 \\
(13.89)\end{array}$ & 9.5 \\
\hline 2 & 3045 & $\begin{array}{l}-0.025 \\
(-4.15)\end{array}$ & $\begin{array}{c}0.387 \\
(11.88)\end{array}$ & 4.4 & $\begin{array}{l}-0.050 \\
(-8.09)\end{array}$ & $\begin{array}{c}0.678 \\
(15.05)\end{array}$ & 6.9 & $\begin{array}{l}-0.049 \\
(-7.92)\end{array}$ & $\begin{array}{l}0.257 \\
(7.66)\end{array}$ & $\begin{array}{c}0.562 \\
(11.90)\end{array}$ & 8.6 \\
\hline 3 & 3041 & $\begin{array}{l}-0.002 \\
(-0.38)\end{array}$ & $\begin{array}{c}0.565 \\
(11.11)\end{array}$ & 3.9 & $\begin{array}{l}-0.038 \\
(-6.09)\end{array}$ & $\begin{array}{c}0.771 \\
(15.56)\end{array}$ & 7.3 & $\begin{array}{l}-0.035 \\
(-5.62)\end{array}$ & $\begin{array}{l}0.329 \\
(6.18)\end{array}$ & $\begin{array}{c}0.654 \\
(12.40)\end{array}$ & 8.5 \\
\hline 4 & 3040 & $\begin{array}{l}-0.009 \\
(-1.59)\end{array}$ & $\begin{array}{c}1.380 \\
(18.41)\end{array}$ & 10.0 & $\begin{array}{l}-0.061 \\
(-9.21)\end{array}$ & $\begin{array}{c}0.988 \\
(17.17)\end{array}$ & 8.8 & $\begin{array}{l}-0.046 \\
(-6.94)\end{array}$ & $\begin{array}{c}0.998 \\
(12.05)\end{array}$ & $\begin{array}{c}0.642 \\
(10.17)\end{array}$ & 12.9 \\
\hline 5 (Highest) & 3035 & $\begin{array}{l}0.004 \\
(0.78)\end{array}$ & $\begin{array}{c}2.195 \\
(18.96)\end{array}$ & 10.6 & $\begin{array}{l}-0.072 \\
(-9.96)\end{array}$ & $\begin{array}{c}1.291 \\
(18.05)\end{array}$ & 9.7 & $\begin{array}{l}-0.049 \\
(-6.67)\end{array}$ & $\begin{array}{c}1.540 \\
(11.85)\end{array}$ & $\begin{array}{c}0.833 \\
(10.43)\end{array}$ & 13.6 \\
\hline
\end{tabular}

Panel A: Earnings persistence measured by ARIMA $(0,1,2)$

Panel B: Test of Earnings Persistence Measured by ARIMA $(0,1,2)$ on Incremental Value Relevance of Earnings Changes and Earnings Levels

\section{Incremental Value Relevance}

(Changes in Adj. $\mathbf{R}^{2}$ )
Incremental Information Content

(Changes in Slope Coefficients (\%)) Incremental $\mathbf{R}_{\mathrm{EPS}}^{2}$ or $\mathbf{R}_{\triangle \mathrm{EPS}}^{2}=\alpha_{0}+\alpha_{1} \tau+\mathrm{e}$ 


\begin{tabular}{|c|c|c|c|c|c|c|c|}
\hline $\begin{array}{l}\text { Dependent } \\
\text { Variable }\end{array}$ & Coefficient & t-statistic & $\begin{array}{c}\text { Adj. } \mathrm{R}^{2} \\
(\%)\end{array}$ & $\begin{array}{l}\text { Dependent } \\
\text { Variable }\end{array}$ & Coefficient & t-statistic & $\begin{array}{c}\text { Adj. } \mathrm{R}^{2} \\
(\%)\end{array}$ \\
\hline Incre_R ${ }_{\text {EPS }}^{2}$ & -0.007 & $(-3.68)^{* *}$ & 75.8 & Incre_Coeff EPS & -0.147 & $(-8.81)^{* *}$ & 95.0 \\
\hline Incre_R ${ }_{\Delta E P S}$ & 0.006 & $(1.79)^{*}$ & 35.3 & Incre_Coeff $_{\triangle \mathrm{EPS}}$ & 0.074 & $(3.69)^{* *}$ & 75.9 \\
\hline
\end{tabular}

Note: The total number of observations is 15,250 firm-years for the period of 1990-2011. Each firm is required to have at least 15 years of annual earnings and to have a non-stationary earnings process. Earnings persistence is estimated from $\left(1-\theta_{1}-\theta_{2}\right)$, where $\theta_{1}$ and $\theta_{2}$ are the firm-specific moving average parameters. All the definitions are the same as the prior tables.

Figure 1 and 2 depict the effects of different earnings persistence measures on the incremental explanatory power of earnings changes and earnings levels. As earnings persistence increases, Figure 1 shows that the incremental explanatory power of earnings levels decreases, but that of earnings changes increases, when different time-series earnings persistence measures - ARIMA $(0,1,1)$, ARIMA $(1,1,0)$ and ARIMA $(0,1,2)$-- are used. The prediction of this paper on the complementary roles, though somehow moderately, is supported. Figure 2, which illustrates effects of different earnings persistence measures on the incremental slope coefficient of earnings changes and earnings levels, leads to a conclusion similar to that of Figure 1.

The graph depicts the effect of earnings persistence measured by various time-serial earnings persistence on the incremental explanatory power (i.e., changes in adjusted $\mathrm{R}^{2}$ ) of earnings levels and earnings changes in the return-earnings relationship. The labels of two figures are defined as follow:

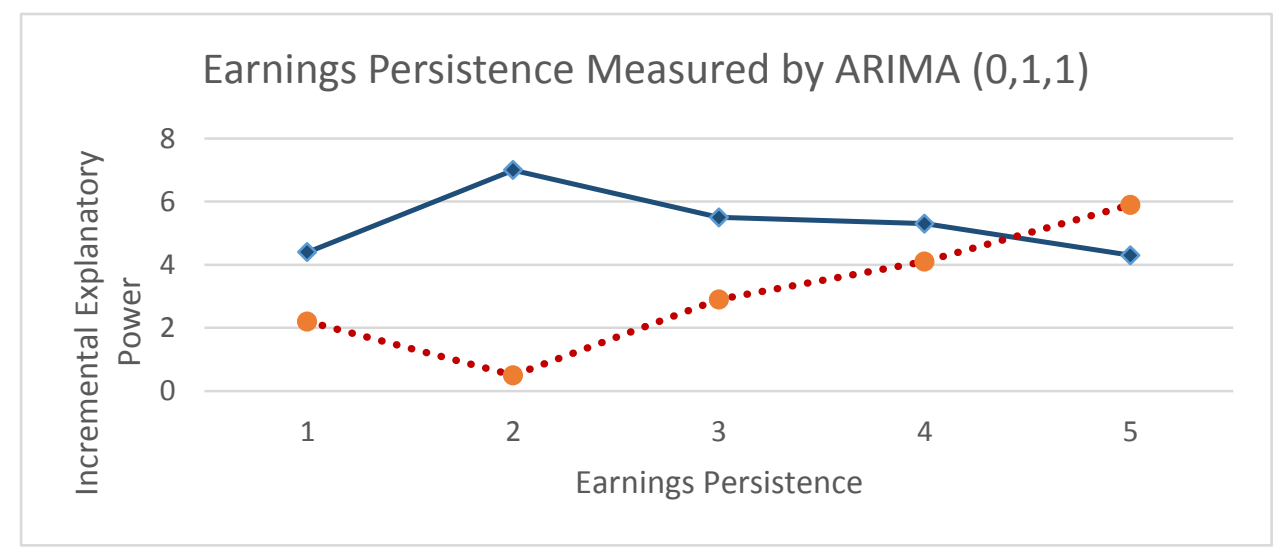



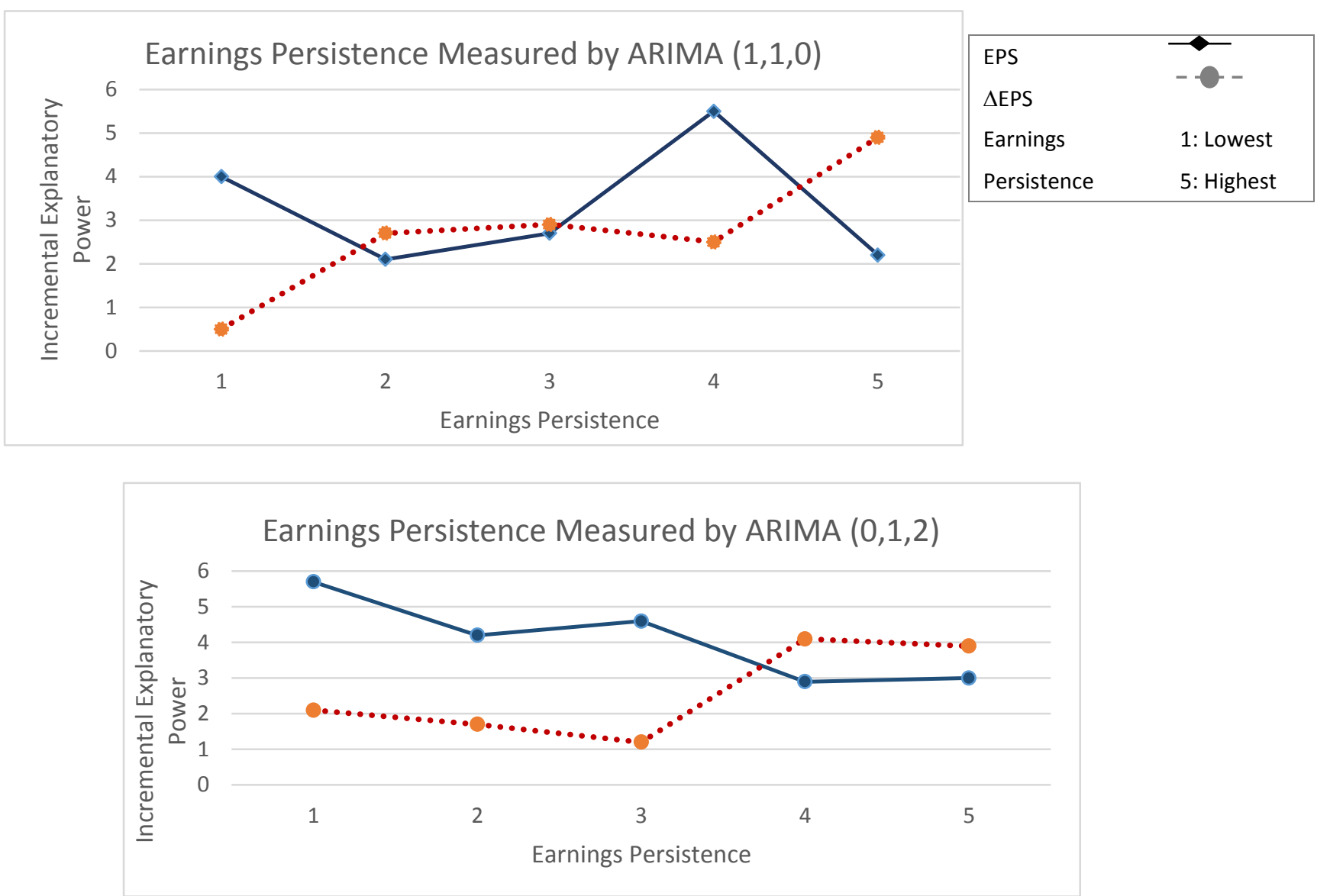

Figure 1. Earnings Persistence and Incremental Explanatory Power

The graph depicts the effect of earnings persistence measured by various time-serial earnings persistence on the incremental information content (i.e., percent change in slope coefficients) of earnings levels and earnings changes in the return-earnings relationship.

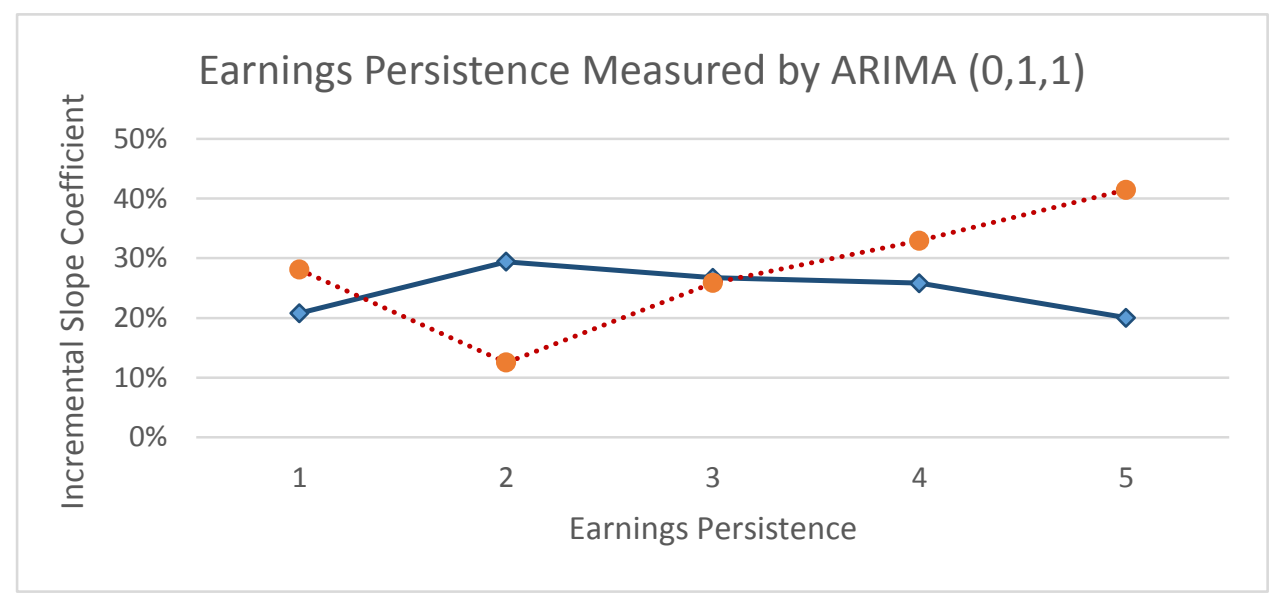



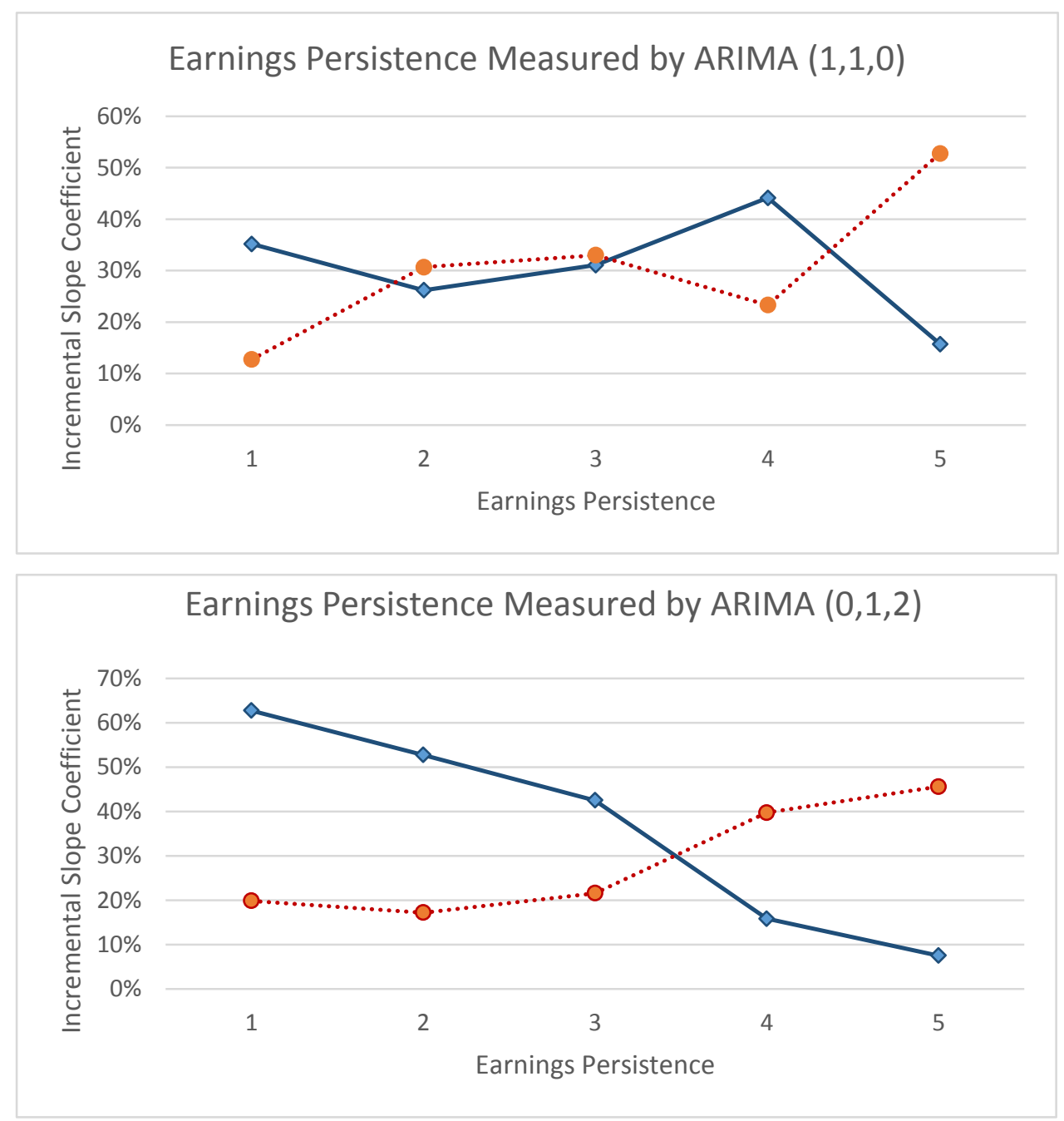

Figure 2. Earnings Persistence and Incremental Information Content

\section{Concluding Remarks and Limitations}

In response to rapid change in accounting practices and mixed results in empirical findings, this paper reexamines the effect of earnings persistence on the incremental value relevance of earnings changes and earnings levels as an explanatory variable for stock returns in the recent years. Prior studies have documented a decline in the value relevance for accounting earnings but report mixed results on the joint relevance of book value and earnings. This paper revisits this issue by using different time-series proxies for earnings persistence to examine the relatively complementary valuation roles between earnings levels and earnings changes in earnings-return relationship as earnings persistence varies.

As both accounting practitioners and academic researchers call for further examinations on earnings persistence and earnings quality in response to rapid changes of the field of accounting in decades, this paper adds evidence to document the weakening joint value relevance of earnings and book value in explaining stock prices. By using different estimates 
of time-series earnings persistence, we find, though somehow marginally but statistically, consistent with the prediction of firm valuation: The higher the earnings persistence, the stronger (lower) the incremental value relevance of earnings changes (level). This paper concludes that time-series properties of earnings persistence are an important attribute to differentiating the information roles for earnings changes and earnings levels, and that the complementary role between two earnings variables seems to weaken over the recent years.

This paper provides a new insight into the examination of a proposed declining relationship between accounting earnings and stock returns in the U.S. market. From a longitudinal earnings process, this paper documents a weakening complementary value relevant role between earnings changes and earnings levels in the recent years. While most studies on the incremental value relevance comparing earnings changes over earnings levels (or vice versa), this study finds that the complementary relevance between the two earnings variables is only marginally and statistically supported in the recent years, implying that equity investors may look into other information as a firm's earnings persistence varies over time. In addition, as many studies focus on the decomposition of earnings to understand the characteristics of earnings persistence, this paper suggests that it is equivalently important to examine the effects of persistence in the return-earnings relationship through the behaviors of accounting earnings variable as a whole for a long run because investors may consider both overall face value and components of earnings for their investment decisions. It would be likely to be biased if researchers and investors only look into the trees, not the whole forest, in the consideration of firm valuation and equity investment.

Our findings, however, are subject to several analytical limitations due to the measurement of earnings persistence and the lack of direct comparisons of earnings persistence across firms over years. Since it takes at least 15 years of earnings changes to estimate a firm-specific and time-series proxy for earnings persistence, a year-to-year comparison for this measure seems inapplicable. Due to the requirement of non-stationary process to estimate a time-series parameter, a large number of firms with small sizes may be dropped from this study. With these limitations in mind, this study suggests the complementary value relevance between earnings levels and earnings changes possibly deteriorate in the recent years for the U.S. stock market.

\section{References}

Ali, A., \& P. Zarowin. (1992a). The role of earnings levels in annual earnings-return studies. Journal of Accounting Research, 30, 286-296.

Ali, A., \& P. Zarowin. (1992b). Persistence versus transitory components of annual earnings and estimation error in earnings response coefficients. Journal of Accounting and Economics, 15, 249-264.

Ali, A., Klein A., \& J. Rosenfeld. (1992). Analysts' use of information about permanent and transitory earnings components in forecasting annual EPS. The Accounting Review, 67, 183-198. 


\section{$\triangle$ Macrothink}

International Journal of Accounting and Financial Reporting ISSN 2162-3082

Baber, W., S. K. Kang, \& K. Kumar. (1998). Accounting earnings and executive compensation: the role of earnings persistence. Journal of Accounting and Economics, 25, 169-193.

Baber, W., S. K. Kang, \& K. Kumar. (1999). The explanatory power of earnings levels vs. earnings changes in the context of executive compensation. The Accounting Review, 74, 459-472.

Baginski, S. P., K. Lorek, L. Willinger, \& B. Branson. (1999). The relationship between economic characteristics and alternative annual earnings persistence measures. The Accounting Review, 74, 15-120.

Balachandran, S., \& P. Mohanram. (2011). Is the decline in the value relevance of accounting driven by increased conservatism. Review in Accounting Studies, 16, 272-301.

Ball, R., \& P. Brown. (1968). An empirical evaluation of accounting income numbers. Journal of Accounting Research, 6, 159-178.

Ball, R., \& R. Watts. (1972). Some time-series properties of accounting income. Journal of Finance, 27, 663-681.

Barth, M. E., W. H. Beaver, \& W. R. Landsman. (1998). Relative valuation roles of equity book value and net income as a function of financial health. Journal of Accounting and Economics, 25, 1-34.

Beaver, R. L., \& D. Morse. (1980). The information content of security prices. Journal of Accounting and Economics, 2, 3-28.

Beaver, W. H. (1970). The time series behavior of earnings, empirical research in accounting: selected studies,Journal of Accounting Research, Supplement to Vol 8., 62-89.

Beveridge, S., \& C. Nelson. (1981). A new approach to decomposition of economic time series into permanent and transitory components with particular attention to measurement of the business cycle. Journal of Monetary Economics, 7, 151-174.

Brooks, L., \& D. Buckmaster. (1976). Further evidence of the time-series properties of accounting income. Journal of Finance, 31, 1359-1273.

Brown, S., K. Lo, \& T. Lys. (1999). Use of $\mathrm{R}^{2}$ in accounting research: measuring changes in value relevance over the last four decades. Journal of Accounting and Economics, 28, 83-116.

Buchheit, S., \& M. Kohlbeck. (2002). Have earnings announcements lost information content?. Journal of Accounting, Auditing, and Finance, 17, 137-153.

Burgstahler, D. (1998). Discussion of combining earnings and book value in equity valuation. Contemporary Accounting Research, 15, 325-341.

Chang, J. (1999). The decline in value relevance of earnings and book value. Working paper, University of Pennsylvania. 


\section{Macrothink}

International Journal of Accounting and Financial Reporting ISSN 2162-3082

Cheng, A., S. Liu, \& T. Schaefer. (1996). Earnings persistence and the incremental information content of cash flows from operations. Journal of Accounting Research, 34, 173-181.

Christie, A. (1987). On cross-sectional analysis in accounting research. Journal of Accounting and Economics, 9, 231-58.

Collins, D.W., \& S. P. Kothari. (1989). An analysis of intertemporal and cross-sectional determinants of earnings response coefficients. Journal of Accounting and Economics, 11, 143-182.

Collins, D.W., E. Maydew, \& I. Weiss. (1997). Changes in the value relevance of earnings and book values over the past forty years. Journal of Accounting and Economics, 24, 39-67.

Collins, D.W., M. Pincus, \& H. Xie. (1999). Equity valuation and negative earnings: the role of book value of equity. The Accounting Review, 74(1), 29-61.

Cready, W., M. J. Lopez, \& C. A. Sisneros. (2010). The Persistence and Market Valuation of Recurring Nonrecurring Items. The Accounting Review, 85(5), 1577-1615.

Dechow, P, Ge, W., \& Schrand, C. (2010). Understanding earnings quality: A review of the proxies, their determinants and their consequence. Journal of Accounting and Economics, 50, 344-401.

Dechow, P, S. A. Richardson, \& R. G Sloan. (2008). The persistence and pricing of cash components of earnings. Journal of Accounting Research, 46(3), 537-566.

Dechow, P., \& I. Dichev. (2002). The quality of accruals and earnings: the role of accrual estimation errors. The Accounting Review, 77, 35-59.

Dichev, I. D., \& V. W. Tang. (2008). Matching and the changing property of accounting earnings over the last 40 years. The Accounting Review, 83(6), 1425-1460.

Dichev, I. D., Graham, J. R. A., Harvey, C. R., \& Rajgopal, S. (2013). Earnings quality: evidence from the field. Journal of Accounting and Economics, 56, 1-33.

Easton P., \& M. Zmijewski. (1989). Cross-sectional variation in the stock market response to accounting earnings. Journal of Accounting \& Economics, 11, 117-142.

Easton P., \& T. Harris. (1991). Earnings as an explanatory variable for returns. Journal of Accounting \& Research, 29, 19-36.

Easton P., P. Eddey, \& T. Harris. (1993). An investigation of revaluations of tangible long-lived assets, Journal of Accounting Research, 31, 1-38.

Fairfield, P. M., J. S. Whisenant, \& T. L. Yohn. (2003). Accrued Earnings and Growth: Implications for Future Profitability and Market Mispricing. The Accounting Review, 78(1), 353-371.

Finger, C. (1994). The ability of earnings to predict future earnings and cash flows. Journal of Accounting Research, 32, 210-223. 


\section{MInstitute Macrothink $_{\text {Int }}$}

International Journal of Accounting and Financial Reporting ISSN 2162-3082

Francis, J., \& K. Schipper. (1999). Have financial statements lost their relevance. Journal of Accounting Research, 37, 319-352.

Francis, J., \& Smith, M. (2005). A reexamination of persistence of cash flows and accruals. Journal of Accounting Research, 43(3), 413-451

Fuller, W. A. (1976). Introduction to Statistical Time Series. John Wiley, New York, NY.

Hanlon, M. (2005). The persistence and pricing of earnings, accruals, and cash flows when firms have large book-tax differences. The Accounting Review, 80(1), 137-166.

Kennedy, P. (1997). A Guide to Econometrics (3rd ed.). The MIT Press, Cambridge, MA.

Kim, M., \& W. Kross. (2005). The ability of earnings to predict future operating cash flows has been increasing, not decreasing. Journal of Accounting Research, 43(5), 753-780.

Kormendi, R., \& R. Lipe. (1987). Earnings innovations, earnings persistence and stock returns. Journal of Business, 60, 323-346.

Kothari, S. P. (2001). Capital markets research in accounting. Journal of Accounting and Economics, 31, 105-231.

Lev, B., \& P. Zarowin. (1999). The boundaries of financial reporting and how to extend them. Journal of Accounting Research, 37, 353-385.

Lev, B., \& R. Thiagarajan. (1993). Fundamental information analysis. Journal of Accounting Research, 31, 190-215.

Lipe, R. (1986). The information contained in the components of earnings. Journal of Accounting Research, 24, 37-64.

Lipe, R. (1990). The Relation Between Stock Returns and Accounting Earnings Given Alternative Formation. Accounting Review, 65, 49-71.

Lipe, R., \& R. Kormendi. (1994). Mean reversion in annual earnings and its implications for security valuation. Review of Quantitative Finance and Accounting, 4, 27-46.

Liu, J., \& J. Thomas. (2000). Stock returns and accounting earnings. Journal of Accounting Research, 38, 71-101.

McInnis, J. (2010). Earnings smoothness, average returns, and implied cost of capital. The Accounting Review, 85(1), 315-341.

Ohlson J. A. (1995). Earnings, book values and dividends in security valuation. Contemporary Accounting Research, 11, Spring, 661-668.

Ohlson, J. A., \& P. K. Shroff. (1992). Changes versus levels in earnings as explanatory variables for returns: some theoretical consideration. Journal of Accounting Research, 30, 210-226.

Ohlson J. A., \& X. Zhang. (1998). Accrual accounting and equity valuation. Journal of Accounting Research, 36, 85-111. 


\section{$\triangle$ Macrothink}

International Journal of Accounting and Financial Reporting

ISSN 2162-3082

Ou, J. A., \& S. H. Penman. (1989). Accounting measurement, price-earnings ratio and the information content of security prices. Journal of Accounting Research, (supplement), 111-152.

Penman, S. (1998). Combining earnings and book values in equity valuation. Contemporary Accounting Research, 15, 291-324.

Penman, S. (2010). Financial statement analysis and security valuation. McGraw-Hill, NY.

Penman, S., \& X. Zhang. (2002). Accounting conservatism, the quality of Earnings, and stock returns. The Accounting Review, 77(2), 237-264.

Ramakrishnan, R., \& J. Thomas. (1998). Valuation of permanent, transitory and price-irrelevant components of reported earnings. Journal of Accounting, Auditing and Finance, 13, 301-336.

Sloan, R. (1996). Do stock prices fully reflect information in accruals and cash flows about future earnings. The Accounting Review, 71(3), 289-315.

Subramanyam, K. R., \& J. J. Wild. (1996). Going-concern status, earnings persistence, and informativeness of earnings. Contemporary Accounting Research, 13, 251-273.

Subramanyam, K. R., \& J. J. Wild. (2009). Financial Statement Analysis. McGraw-Hill.

Theil, H. (1971). Principle of Econometrics. Wiley, New York, NY.

Vuong, Q. H. 1989). Likelihood ratio tests for model selection and non-nested hypotheses. Econometrica, 57, 307-333.

Wang, Z. (2014). Measuring investors' assessment of earnings persistence: do investors see through smoothed earnings?. Review of Quantitative Finance and Accounting, 42, 691-708.

Xie, H. (2001). The Mispricing of abnormal accruals. The Accounting Review, 76(3), 357-373.

Zhang, X. (2000). Conservative accounting and equity valuation. Journal of Accounting \& Economics, 29, 125-149. 


\section{Appendix A}

Using Earnings Levels and Earnings Changes as Proxies for Unexpected Earnings in ARIMA $(0,1,1)$ and ARIMA $(0,1,2)$ Time-series Processes

In the text, we have shown that unexpected earnings can be represented as a weighted average of earnings changes and earnings levels in an ARIMA $(0,1,1)$ time-series earnings process. In this appendix, we show that a similar approach can be applied to ARIMA $(1,1,0)$ and ARIMA $(0,1,2)$ processes of earnings.

For earnings that follow an ARIMA $(1,1,0)$ process, it can be represented as:

$$
\Delta \mathrm{X}_{\mathrm{t}}=\varphi \Delta \mathrm{X}_{\mathrm{t}-1}+\mathrm{e}_{\mathrm{t}}
$$

where $\varphi$ is an autoregressive parameter, $e_{t}$ is the unexpected earnings, and $\Delta X_{t}$ is the change in earnings. Using a lag operator L, equation (A1) can be rearranged as:

$$
\begin{aligned}
& e_{t}=(1-\varphi L) \Delta X_{t} \\
(1-\varphi) & e_{t}=(1-\varphi)(1-\varphi L) \Delta X_{t} \\
= & (1-\varphi)(1-\varphi L)\left(X_{t}-X_{t-1}\right) \\
= & \Delta X_{t}+(-\varphi) X_{t}+\varphi^{2} X_{t-1}+\varphi(1-\varphi) X_{t-2} .
\end{aligned}
$$

Following Ali and Zarowin (1992a) and Baber et al. (1999), we suppress X beyond t-1 so that equation (A3) can be rewritten as:

$$
\mathrm{e}_{\mathrm{t}}=[1 /(1-\varphi)] \Delta \mathrm{X}_{\mathrm{t}}+[(-\varphi) /(1-\varphi)] \mathrm{X}_{\mathrm{t}}
$$

When the autoregressive parameter $\varphi$ of the ARIMA $(1,1,0)$ process is equal to 0 , earnings follow a random walk model. Earnings changes, $\Delta X_{t}$, are the best approximation for unexpected earnings and current earnings levels do not have the ability to approximate unexpected earnings.

If autoregressive parameter $\varphi$ falls between -1 and 0 , it indicates that earnings changes are negatively serially correlated (Dechow (1994)). An increase in $\varphi$ results in a decrease in $[1 /(1-\varphi)]$ and an increase in $[(-\varphi) /(1-\varphi)]$. As $\varphi$ increases, the relative weight on earnings changes decreases and that on earnings levels increases. When $\varphi$ falls between $(0,1)$, the weight on earnings changes increases, but the weight on current earnings levels becomes more negative as $\varphi$ increases. In either case, the linear combination of earnings changes and earnings levels still provides an estimate of contemporaneous unexpected earnings when autoregressive parameter varies.

Alternatively, if earnings follow an ARIMA $(0,1,2)$ process, it can be represented as:

$$
\begin{aligned}
\Delta \mathrm{X}_{\mathrm{t}} & =\mathrm{e}_{\mathrm{t}}-\theta_{1} \mathrm{e}_{\mathrm{t}-1}-\theta_{2} \mathrm{e}_{\mathrm{t}-2} \\
& =\mathrm{e}_{\mathrm{t}}-\left(\theta_{1}+\theta_{2} \mathrm{~L}\right) \mathrm{e}_{\mathrm{t}-1},
\end{aligned}
$$

where $\theta_{1}$ and $\theta_{2}$ are moving average parameters, $e_{t}$ is unexpected earnings, $\Delta X_{t}$ is the change in earnings, and $\mathrm{L}$ is a lag operator. 


\section{Mll Macrothink}

International Journal of Accounting and Financial Reporting

(A.5) can be rewritten as

$$
\mathrm{e}_{\mathrm{t}}=\mathrm{X}_{\mathrm{t}}-\left(1-\theta_{1}-\theta_{2} \mathrm{~L}\right) \mathrm{X}_{\mathrm{t}-1}-\left(\theta_{1}+\theta_{2} \mathrm{~L}\right)\left(1-\theta_{1}-\theta_{2} \mathrm{~L}\right) \mathrm{X}_{\mathrm{t}-2}+\ldots
$$

Suppressing lagged terms in $X$ beyond $t-1$ and assuming $\theta_{2} X_{t-1}=\theta_{2} X_{t-2}$, the above equation becomes: (Note 6)

$$
\mathrm{e}_{\mathrm{t}}=\left(1-\theta_{1}-\theta_{2}\right) \Delta \mathrm{X}_{\mathrm{t}}+\left(\theta_{1}+\theta_{2}\right) \mathrm{X}_{\mathrm{t}}
$$

For earnings following an ARIMA $(0,1,2)$ process, the weight on earnings changes in approximating unexpected earnings increases as the persistence measure, $\left(1-\theta_{1}-\theta_{2}\right)$, increases. In contrast, the weight on earnings levels in unexpected earnings increases when earnings contain more temporary components (i.e. larger $\left(\theta_{1}+\theta_{2}\right)$ ).

\section{Notes}

Note 1. This study follows prior studies (e.g., Balachandran and Mohanram (2011), Francis and Schipper (1999), and Collins, Maydew and Weiss (1997)) examining the valuation roles of earnings and book value and uses "value relevance" to describe whether accounting information is consistently related to security prices. As such, value relevance is measured by two components: explanatory power and information content. The "information content" is used to indicate the extent that the market is associated with accounting earnings variables and is estimated from the regression coefficients for earnings variables in an annual window. The "explanatory power", as measured by regression $\mathrm{R}^{2}$ ' $\mathrm{s}$, is used to indicate the extent that the variations of stock returns can be explained by earnings variables.

Note 2. Other contexts in which earnings persistence has been investigated include economic and marketing characteristics (Baginski et al. (1999)), analyst analysis (Ali, Klein and Rosenfeld (1992)), compensation agreements (Baber, Kang and Kumar (1998)), stock prices (Ramakrishnan and Thomas (1998), Ali and Zarowin (1992b)), and equity valuation (Ohlson (1995)).

Note 3. Several special cases in prior studies are derived from this equation as well. If no dividends and no other value relevant information are assumed, the relative weight, $\mathrm{k}=\left(\mathrm{P}_{\mathrm{t}}-\right.$ $\left.B_{\mathrm{t}}\right) /\left(\rho \mathrm{X}_{\mathrm{t}}-B_{\mathrm{t}}\right)$, can also be used as an alternative way of analysis adopted by Penman (1998) and Burgstahler (1998). Ohlson and Zhang (1998) refer to $\mathrm{k}=0$ as "mark-to-market (or transitory)" and $\mathrm{k}=1$ as "permanent earnings" accounting.

Note 4. Consider the reciprocal relation: $1 / \mathrm{k}=(1+\mathrm{r}-\omega) /(\mathrm{r} \omega)=\rho / \mathrm{r} \omega-1 / \mathrm{r}$. If a constant discount rate $r$ (thus $\rho$ ) is assumed, then the weighting factor, $k$, is directly related to the persistence measure, $\omega$, of abnormal earnings. Also see explanations in Ohlson (1995), indicating that $(1-\omega)$ and $\omega$ are related to a weighted average of two dynamic information sets. Gode and Ohslon (2000) relax the assumption of fixed discount rate and show that abnormal earnings persistence depends on current and lagged interest rates. 


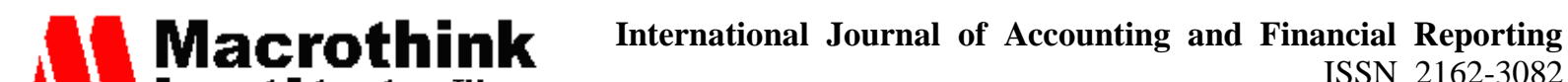 Institute ${ }^{\mathrm{TM}}$

Note 5. To test the non-stationarity of the earnings, we implement the augmented Dickey-Fuller (ADF) regression:

$$
\Delta \mathrm{EPS}_{\mathrm{t}}=\alpha_{0}+\alpha \mathrm{EPS}_{\mathrm{t}-1}+\sum_{\mathrm{i}=0}^{\mathrm{m}} \Delta \mathrm{EPS}_{\mathrm{t}-\mathrm{i}}+v_{\mathrm{t}}
$$

A unit root or non-stationarity is rejected when the null hypothesis $\alpha=0$ is rejected (Fuller (1976)). We choose to use firms with non-stationary earnings for the following reasons. First, the time-series properties will be seriously misspecified without determining the stationarity or a unit root process (Finger (1994)). Second, Beveridge and Nelson (1981) assert that non-stationary earnings contain both persistent and transitory components, but stationary earnings contain only transitory components of earnings. Third, Kennedy (1997) maintains that stationarity is a primary criterion for the use of time series forecast models so we use an integration process (i.e., first differencing) in non-stationary earnings to achieve stationarity. Earnings persistence is manifested by persistent components of earnings, which exist only in a non-stationary earnings process. The inclusion of stationary earnings changes and levels induces estimation errors and generates a downward bias on value relevance.

Note 6. If the relation $\theta_{2} \mathrm{X}_{\mathrm{t}-1}=\theta_{2} \mathrm{X}_{\mathrm{t}-2}$ is not assumed, the suppression of lagged earnings beyond $t-1$ will yield $e_{t}=X_{t}-\left(1-\theta_{1}\right) X_{t-1}$, which is the same specification as earnings following an ARIMA $(0,1,1)$ process. Thus, the effect of the second moving average parameter, $\theta_{2}$, will be dropped off from the analysis.

\section{Copyright Disclaimer}

Copyright for this article is retained by the author(s), with first publication rights granted to the journal.

This is an open-access article distributed under the terms and conditions of the Creative Commons Attribution license (http://creativecommons.org/licenses/by/4.0/) 